\title{
8. National Competition Policy and Cooperative Federalism
}

\author{
Jeffrey Harwood and John Phillimore
}

\section{Introduction}

The National Competition Policy (NCP) is widely regarded as one of Australia's most successful examples of cooperative federalism. Through the Council of Australian Governments (COAG), the Commonwealth, states and territories agreed in 1995 to implement a set of microeconomic reforms focused on removing impediments to equal competition between public and private businesses and creating competitive pricing and regulatory mechanisms for utility services and road transport. In return for the successful implementation of the reform package, the Commonwealth transferred payments to the states and territories. The NCP was subsequently commended as an economic success by the Productivity Commission (2005). However, whether it should be regarded as a successful example of cooperative federalism is a matter deserving further consideration.

For some, the NCP comprised soundly based policy goals and realised worthwhile microeconomic reforms that states and territories would not otherwise have achieved (see, for example, Banks 2005; Productivity Commission 2005; Sims 1999; Thomas 1996). However, there are some critical views that the nature and implementation of the NCP favoured the Commonwealth, threatened community service obligations, did not take into sufficient account regional needs and failed to achieve the environmental benefits envisaged to flow on from more efficient markets, especially in the case of rural water schemes (see, for example, Butler 1996; Boswell 1996; Carver 1996; Fenna 2007; Hollander 2006; Hollander and Curran 2001).

This chapter evaluates the NCP as an example of cooperative federalism. After providing an account of the way the NCP came into being, was implemented and evolved, we consider the competing interpretations. In assessing those propositions, we draw upon discussions with six senior policy officers from various agencies in four states who were responsible for its implementation, and from the National Competition Council (NCC). A close reading of NCP documents further enlightens our evaluation. Our conclusion is that while in many respects a good example of Australian governments working together, the NCP was ultimately too coercive in its application to constitute an entirely successful example of cooperative federalism. 


\section{The National Competition Policy}

The decision by COAG (COAG 1995a, 1995b) to implement the NCP was the culmination of an economic reform process that began with the floating of the Australian dollar in 1983. This was followed by further deregulation of financial markets and a series of sectoral plans designed to promote industrial development and locally manufactured exports. Tariffs were subsequently lowered in the motor vehicle, textile, clothing and footwear, and telecommunications sectors. While these reforms were intended to make the private sector more competitive, less attention was being paid to the public sector. Following the release of the National Competition Policy Review Report (Hilmer et al. 1993), however, attention shifted to the structural reform of government utilities, regulatory and pricing frameworks, and the extent to which government legislation supported or undermined competition. The solution, it was argued, was the application of market-based policy instruments to the public sector.

As Painter (1998, pp. 81-89) has explained in detail, the resulting NCP was forged through both conflict and cooperation. The then Prime Minister, Paul Keating, was anxious to implement Hilmer's proposed reforms and was prepared to impose these upon the states. On the other hand, the states were arguably in their strongest position vis-à-vis the Commonwealth. The NCP called for the reform of government business enterprises, notably the network utilities; however, these were state government instrumentalities and the Commonwealth needed the states' cooperation for such reforms to proceed. Although the High Court had not stopped the Commonwealth from encroaching upon the states' traditional policy jurisdictions, it had been reluctant to intervene in support of the Commonwealth in matters affecting the institutional governance of the states. The states were in an unusually strong position.

The states, though, were prepared to cooperate with the Commonwealth. Importantly, from the states' perspective, the NCP would not directly expand Commonwealth powers. Moreover, most states had Liberal-led governments at the time that had already initiated microeconomic reforms within their jurisdictions (Painter 1998, p. 82). ${ }^{1}$ In this respect, there was policy convergence between state and Commonwealth central agencies - what Painter (1998, p. 83) referred to as the 'central agency club' — in which the focus was on achieving certain economic outcomes, rather than following federal principles. The outcome was a compromise, with the Commonwealth agreeing to the states being responsible for implementing the NCP in return for payments upon

1 For most of the negotiations over the NCP in 1994-1995, only the Commonwealth, Queensland and the Australian Capital Territory had Labor governments. However, just before the intergovernmental agreements were signed at the April 1995 COAG meeting, a Liberal government took office in the Australian Capital Territory (February) and the Labor Party won government in New South Wales (March). 
meeting particular policy milestones (Painter 1988, pp. 88-89). Furthermore, membership of the two institutions created to administer the NCP - the NCC and the Australian Competition and Consumer Commission (ACCC) - would require the majority approval of the states and territories. By accepting the need for national uniformity under the NCP and the use of template legislation to achieve this objective, the states relinquished their legislative sovereignty. Hence, at the fifth COAG meeting, held in Canberra on 11 April 1995, the respective parties signed the three intergovernmental agreements that provided the foundation of the NCP.

\section{The institutional components}

The NCP comprised three intergovernmental agreements (IGAs) and an Act of the Commonwealth Parliament. First, by signing the Competition Principles Agreement 1995 (NCC 1998), the respective governments agreed to:

- implement the concept of 'competitive neutrality', such that private and government businesses could compete equally;

- establish mechanisms that prevented government business enterprises from exploiting their monopolies;

- the structural reform of public monopolies;

- rationalise the regulatory and pricing frameworks of water, gas and electricity utilities, along with the road transport sector;

- $\quad$ establish a national access regime designed to facilitate sharing of 'essential infrastructure' among competing businesses; and

- amend laws that hinder competition, except in cases found to be in the public interest.

The second IGA was the Conduct Code Agreement 1995 (NCC 1998), which required the amendment and use of the Trade Practices Act 1974 to prevent anti-competitive behaviour by government and unincorporated businesses.

Third, the Agreement to Implement the National Competition Policy and Related Reforms (Implementation Agreement) 1995 (NCC 1998) specified an arrangement whereby the Commonwealth would compensate the states and territories some of the costs of implementing the NCP. The Commonwealth agreed to maintain the per capita financial assistance grants to the states and territories and provide competition payments upon satisfactory progress in implementing NCP reforms. This was intended to reflect the fact that, although the benefits of greater competition flow on to the community in general, the direct fiscal benefits tend to 
flow to the Commonwealth in the form of increased taxation revenue. In addition, the states would lose dividend income from their public utilities (which could be substantial and which, moreover, could be tapped at will). It was estimated that the competition payments would cost the Commonwealth $\$ 4.2$ billion (in 1994-95 prices) over the nine years of the policy (COAG 1995b, 1995c).

The final component of the NCP was the Competition Policy Reform Act 1995 (Commonwealth of Australia 1995), which established the NCC under the Trade Practices Act 1974. Part IIA of the Trade Practices Act established the NCC with a Council President and maximum of four councillors serving terms of no more than five years. (Initially, the councillors were jointly appointed by the Commonwealth, states and territories for a period of three years, and supported by a secretariat of 12 officials, some of whom were on secondment from subnational jurisdictions). As such, the NCC was a Commonwealth statutory body, whose role was to advise the Commonwealth, states and territories on (rather than implement) the NCP. The NCC was also responsible for assessing individual state and territory governments' progress in implementing the reforms, ascertaining whether they had made sufficient progress to receive their compensation payments, recommending to the Commonwealth Treasurer whether the respective governments should receive their competition payments and making available to the public information about the details and progress of the NCP.

The Competition Policy Reform Act 1995 also established the ACCC under the Trade Practices Act 1974. Part II of the Trade Practices Act 1974 made provision for a Commission Chairperson and any number of other commission members to have terms of up to five years. As in the case of the NCC, a majority of states and territories had to agree with appointments for them to be confirmed. The ACCC was made responsible for administering the Trade Practices Act 1974, informing businesses and consumers about their obligations and rights under the Act, and acting as an oversight body to identify cases of price fixing and market sharing and report these to the relevant authorities.

\section{Implementation}

\section{National access regime}

In accordance with the NCP, a national access regime was established, along with various industry specific access regimes. The ACCC was made responsible for administering the regime. Some of the industry regimes - for example, rail networks, ports and electricity distribution networks - came under the jurisdiction of state and territory legislation and were administered by the relevant state and territory oversight authorities. 


\section{Competitive neutrality}

All states and territories implemented competitive neutrality principles to ensure that government and private businesses could compete on equal terms. Guidelines were published to inform the respective parties of their obligations and complaints handling offices were established. Independent oversight bodies were also established to monitor and regulate the prices set by monopoly providers. For example, the Economic Regulation Authority was established by the government of Western Australia in January 2004 to monitor that state's electricity, gas and water sectors, ensure that the respective access and pricing regimes are consistent with the relevant pieces of legislation, to promote and monitor the use of customer charters, and to carry out inquiries when required by the state government (ERA 2009).

\section{Application of the Trade Practices Act 1974}

In 1996, the Competition Code (Part XIA) was added to the Trade Practices Act 1974. This allowed the states and territories to incorporate a version of Part 4 of the Act, the Competition Code, to cover their jurisdictions. Consequently, state and territory governments, unincorporated bodies and government business enterprises were no longer exempt from engaging in anti-competitive practices (unless given permission to do so by the ACCC on grounds of public interest). The states and territories agreed to this and they passed the necessary legislation by July 1996 (Productivity Commission 2005, p. 13).

\section{Legislative reforms}

It was originally estimated that the review and reform of legislation deemed anti-competitive would be finished by 2000 in accordance with clause 5 of the Competition Principles Agreement. COAG subsequently extended the time of review to 30 June 2002. An additional 12 months was later granted by the NCC $(2003,4.1)$, but with the cautionary note:

Review and/or reform activity that is incomplete or not consistent with NCP principles at June 2003 will be considered to not comply with NCP obligations. Where noncompliance is significant ... the Council is likely to make adverse recommendations on payments.

Table 1 sets out the annual payments made to the states and territories and the penalties imposed by the Commonwealth. 
New Accountabilities, New Challenges

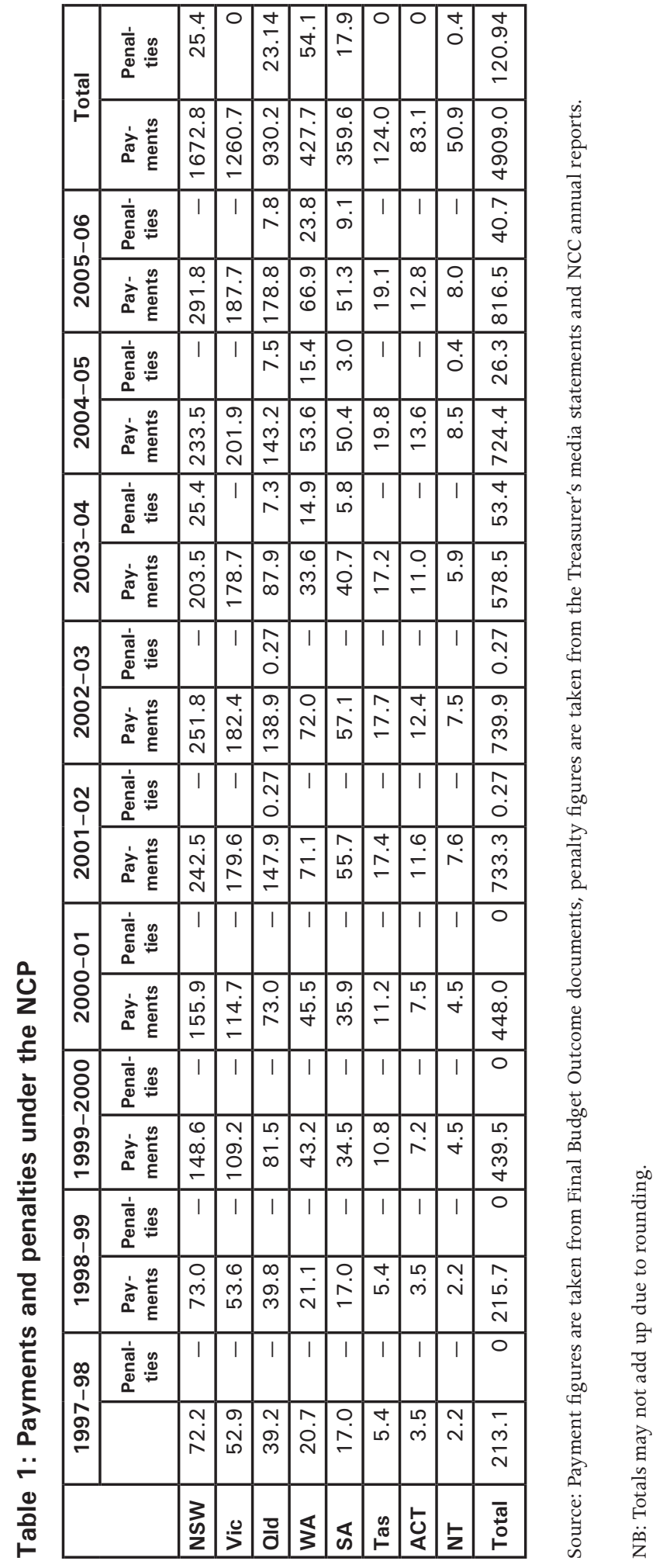


Although an occasionally contentious component of the NCP, the legislative review and reform requirement was generally met. In 2001, the NCC decided to differentiate between priority and non-priority legislation. The former were seen to have a much greater impact upon competition so that their review and reform would provide the most benefit to the wider community. Thus, in assessing whether the progress of the individual states and territories was sufficient to recommend to the Treasurer that they receive their competition payments, completion of the priority legislation reviews was pivotal.

The NCC $(2005,9.6)$ subsequently recommended that the states and territories be penalised and they responded accordingly by finishing most of the reviews by 2005 (see Table 2).

Table 2: Completion rates of legislative reform (1995-2005)

\begin{tabular}{|c|c|c|c|}
\hline \multirow[t]{2}{*}{ Federal jurisdictions } & \multicolumn{3}{|c|}{$\begin{array}{l}\text { Percentage of legislative reform completed } \\
\qquad(1995-2005)\end{array}$} \\
\hline & Priority & Non-priority & Total \\
\hline Australian Capital Territory & 82 & 98 & 93 \\
\hline Commonwealth & 64 & 89 & 78 \\
\hline New South Wales & 88 & 94 & 91 \\
\hline Northern Territory & 82 & 90 & 85 \\
\hline Queensland & 85 & 92 & 87 \\
\hline South Australia & 69 & 94 & 83 \\
\hline Tasmania & 84 & 96 & 91 \\
\hline Victoria & 84 & 91 & 88 \\
\hline Western Australia & 55 & 77 & 68 \\
\hline
\end{tabular}

Source: NCC 2005

While the access regimes, competitive neutrality, the Trade Practices Act 1974, and the legislative reviews were implemented to improve competition in general, they were also applied more specifically to key infrastructure: water, gas, electricity and road transport.

\section{Water}

The so-called 'water reforms' agreed to as part of the NCP were intended to address the widely-held view that Australia's water industry was unsustainable and inefficient. It was agreed by COAG $(1994 a, 1994 b)$ that overuse of urban and rural supplies and the environmental degradation of water supplies necessitated a package of reforms to address these issues. The package included institutional, pricing, investment, allocation, and trading reforms. The institutional reforms entailed corporatising water utilities by 1998, separating responsibility for 
resource management, standards, compliance and provision of services, and the establishment of integrated resource management mechanisms. It was also agreed to implement pricing reforms that comprised consumption-based pricing mechanisms, withdraw cross-subsidies where possible, and make transparent the subsidies that remain. Investment reforms were implemented to ensure that further infrastructure developments were environmentally acceptable and economically viable. Finally, it was agreed that water should be allocated on the basis of effect upon the environment, that land title and water rights should be detached, that entitlement be based upon 'ownership, volume, reliability, transferability and, if appropriate, quality', and trading in allocations and entitlements be introduced by 1998 .

By the end of 2004, the states and territories had made substantial progress on the implementation of these reforms. Water utilities had been corporatised or, in the case of South Australia, contracted out to the private sector, and the service provision and regulatory divisions had been separated (Productivity Commission 2005, p. 27). Furthermore, all participants had passed legislation to separate land title from water entitlements, and established requirements for environmental assessments. The NCC (2003, p. xiv) attributed delays in reforms to the conflicting interests of the various stakeholders, and to the difficulty in reconciling 'the diversity of administrative and legislative environments across jurisdictions'.

\section{Gas}

Like the electricity industry, the gas industry was characterised by vertically integrated government monopolies, which strictly regulated gas suppliers (Productivity Commission 2005, pp. 23-24). Legislation controlled the distribution of gas both within and between states and territories. The states and territories successfully implemented the requisite reforms identified as essential for a competitive gas industry. These reforms included the separation of the transmission and distribution operations; rescinding legislation and regulations that prevented states and territories trading in gas; the institution of the National Gas Access Code to facilitate 'third party access to gas transmission and distribution pipelines'; the corporatisation of government gas authorities; and the introduction of fully competitive retail markets.

\section{Electricity}

Prior to the NCP, the Australian electricity market was highly regulated and dominated by government-owned and vertically integrated utilities that were bounded by state borders (Productivity Commission 2005, p. 21). Consequently, electricity prices were unnecessarily high and oversupply was the norm. The 
proposed solution was the creation in 1998 of a national electricity market, comprising all states and territories except Western Australia and the Northern Territory. The Productivity Commission (2005, p. 22) subsequently reported that most governments met their requirements. Certainly, all had established mechanisms to allow third party access to network infrastructure. The stateowned utilities, whether privatised, leased or corporatised, had been broken up into their constituent parts - generation, distribution, regulation and retail. Under this policy of vertical disaggregation, most large customers could choose their supplier, as could most domestic users.

However, a fully competitive national electricity market was not realised. The Productivity Commission (2005, p. 22) attributed this to insufficient grid interconnection, which meant that potential users were unable to access various suppliers; too few generators to stimulate competition upstream; price signals to residential users that were 'inflexible'; the existence of multiple regulators (that is, one in each sub-national jurisdiction); and a lack of competition in electricity generation.

\section{Transport}

The road transport industry had long been covered by the various rules and regulations of each sub-national jurisdiction (Productivity Commission 2005, p. 25). This imposed costs on users which were, in turn, passed onto consumers. The primary objectives of the NCP reforms were to reconcile the costs with heavy vehicle charges, and replace the various state and territory regimes with a national regulatory framework. It was envisaged that such a framework would include a national heavy vehicle registration scheme, agreement between the jurisdictions over the transporting of dangerous products, roadworthiness, driving hours and the regulation of oversized vehicles, and a mechanism to ensure compliance with the framework.

Apart from matters pertaining to licensing and registration, the states and territories had completed most of the proposed NCP transport reforms by the time of the 2005 assessment by the $\operatorname{NCC}(2005,8.1)$. The NCC $(2005,8.2-5)$ noted that the Commonwealth had yet to pass legislation enabling a national heavy vehicle registration scheme, while the Australian Capital Territory was still deliberating over how to regulate the renewal of heavy vehicle registrations. Western Australia had two remaining reforms to address concerning the local introduction of the national drivers' licence classifications and the adoption of a single, nationally valid, drivers' licence, although the legislation for these was being debated in the Western Australian Parliament. 


\section{Other reforms}

Although the NCP is notable for its application to public utilities and the road transport industry, it was applied to many other industries in ways that were sometimes resisted by stakeholders and the Commonwealth, state and territory governments, leading to sub-national governments being penalised financially under the NCP (see Table 2). Elements of the agriculture industry were especially opposed to reforms proposed under the NCP. For example, there was considerable opposition to the removal of the Australian Wheat Board's effective monopoly over wheat exports. Despite the NCC's call for the Wheat Marketing Act 1989 to be revised or revoked, the Commonwealth refused to deregulate the wheat export industry. Likewise, the Western Australian government was steadfast in its refusal to deregulate potato marketing; unlike the Commonwealth, it was subsequently penalised a total of $\$ 7.5 \mathrm{~m}$.

The pharmacy sector was another that successfully avoided deregulation and evidenced the Commonwealth's 'flexibility' in applying COAG agreements in contrast to the NCC's 'literal' interpretations. The National Competition Policy Review of Pharmacy Regulation reported to COAG in 2000 and recommended that the states and territories be required to remove all restrictions on the number of pharmacies that could be owned by a single pharmacist, but also recommended that limits be placed on the number of pharmacies controlled by individual friendly societies within a jurisdiction. The first recommendation was supported by a COAG working group and accepted by COAG (NCC 2005, 19.9-10). The working group rejected the second recommendation and COAG accepted its counter-proposal that individual friendly societies be free to operate under the same conditions of ownership as pharmacists. In 2004, however, with every sub-national jurisdiction yet to completely deregulate pharmacy ownership, the Prime Minister informed each of the states and territories that they would not incur penalties provided they legislated minimum limits of ownership as stipulated by him. Nevertheless, the NCC (2005) still noted that by not deregulating the pharmacy industry, each sub-national government was failing to meet its obligations under the Competition Principles Agreement.

However, not all the states and territories felt the wrath of the NCC. Victoria, Tasmania and the Australian Capital Territory did not suffer permanent deductions as a consequence of adverse findings by the NCC. The other jurisdictions were penalised for a variety of reasons. Permanent deductions were applied to New South Wales for failing to deregulate rice marketing, liquor sales marketing, and the chicken meat industry. Queensland was penalised for failing to deregulate liquor sales marketing and making insufficient progress on water reforms. Western Australia was punished for failing to deregulate retail trading hours, liquor sales marketing and potato marketing, and for having outstanding legislation review items. South Australia was also penalised for 
having outstanding legislation review items, as well as failing to deregulate the chicken meat industry, liquor sales marketing, and barley marketing. Finally, the Northern Territory was subjected to permanent deductions for not deregulating liquor sales marketing.

\section{NCP as an exemplar of cooperative federalism}

The NCP is often promoted as an exemplar of collaborative federalism, an initiative that realised worthwhile reforms that states and territories would not otherwise have achieved. The Western Australia Chamber of Commerce and Industry, for example, described the NCP as 'one of the greatest achievements of cooperative federalism in recent years' (CCIWA 2007, p. 7). Typically, such views are expressed because of the economic outcomes that NCP has delivered, the positive role of the NCC as a purportedly neutral arbiter between the Commonwealth and the states and territories, and the use of incentive payments to encourage scheduled implementation of the NCP reforms.

\section{Measurable economic success}

First and foremost, the microeconomic reforms that the NCP brought about are widely seen as being in the national interest. In its report on the NCP, for example, the Productivity Commission (2005, p. 40) used the growth in multifactor productivity (MFP) — 'the efficiency with which both labour and capital inputs are used in production' - as its primary indicator of improved economic performance. The Productivity Commission (2005, p. 46) found that MFP in the telecommunications sector had evidenced an annual seven per cent increase from 1996-97 to 1999-2000, while MFP in the postal services sector had increased 3.5 per cent per annum over the period from 1992 to 2002. Overall, the Productivity Commission (2005, p. 35) estimated that the NCP has contributed a 'permanent increase' of at least 2.5 per cent in Australia's GDP.

\section{Governance}

Second, officers interviewed regarded the NCC as a fair and reasonable broker in its negotiations with the states and territories. They attributed this to the relative autonomy of the NCC, the professionalism of the officers involved and the mechanism through which the NCC operated, notably, the procedure by which the NCC forwarded a draft report to the states and territories, allowed them the opportunity to respond and, then, negotiate a deal with the NCC. 


\section{Reform funding}

The incentive payments are almost universally regarded as being crucial to the successful implementation of the NCP. By enabling them to highlight the cost of not pursuing reforms, central agency ministers were able to win over their colleagues in Cabinet meetings. Moreover, local media publicised the potential loss of revenue and politicians had to justify delays in implementing NCP reforms. In this way, everybody could ascertain whether it was worth sacrificing the incentive payment to maintain the policy status quo. Western Australia's decision not to deregulate shopping hours, for example, could only be justified by the Western Australian government after holding a referendum.

Those who saw the NCP as a successful example of cooperative federalism emphasised the initial process and policy outcomes. For them, cooperation meant collaboration over policy formulation and a signed agreement. Success was measured in terms of achieving microeconomic reforms and improvements in economic productivity that could be associated with the reforms.

\section{NCP as less-than-ideal cooperative federalism}

Despite the praise lavished on the NCP as a positive example of cooperative federalism, it also received its share of criticism during and after its implementation. Although the NCP was premised upon agreement between the federal partners, some within the states and territories felt that it did not treat equally all levels of government, that the review process of the NCC was not sufficiently transparent, and that the demands to comply with the NCP threatened state autonomy.

\section{Inequitable treatment}

Perhaps the most consistent criticism was that the NCP framework did not hold the Commonwealth accountable for implementing reforms the same way it did the states (NCC 2004, p. 39; New South Wales Government 2004, pp. 18, 20). The objective of the payments mechanism under the NCP was to act as an incentive - albeit a negative incentive - to discourage inaction by the respective sublevels of governments. However, the mechanism did not extend to include the Commonwealth, despite the fact that by the time that the NCC had completed its final assessment of legislative reviews, the Commonwealth had reviewed only 78 per cent of its legislation. This meant that some officials saw the NCC as a 'policeman' for the Commonwealth to cajole the states and territories into doing its bidding. 


\section{Lack of transparency}

The review mechanism of the NCP reinforced the belief of some states that the NCC and the Commonwealth were working together to impose policy upon the states. The Victorian government (Victoria 2004, p. 15), for example, voiced its frustration that the NCP did not contain a formal process after the annual submission by the states. Although the states and territories could see and comment upon the draft report, they were not shown the recommendations. Furthermore, there was no logical framework for NCC decisions and its recommendations as to whether penalties should be applied.

The NCC (2004, p. 39) acknowledged that transparency was lacking in the reporting processes. It pointed out that it was not to blame: there was nothing requiring it to make its reviews public. It also explained that some reports were not released because they were unpopular with government. By making all reports public, governments would be compelled to follow processes and meet acceptable standards. Moreover, such reports needed to meet consultation standards that would be acceptable to stakeholders and the wider community.

\section{State policy autonomy challenged}

A more fundamental criticism of the NCP was that it was a national, rather than federal policy, which diminished the policy autonomy of the states and territories (Fenna 2007, pp. 189-190). Significant parts of the NCP, though - indeed, perhaps the bulk of the NCP - concerned collective goods whose boundaries in most respects do not exceed sub-national jurisdictions. Moreover, the inclusion of financial incentives undermined the idea of states and territories proceeding in a federal fashion, that is, in their own direction at their own speed. Thus, it could be said that the uniform national approach reflected a common view that this was the best policy approach to take, rather than any need for policy uniformity per se due to inter-jurisdictional inefficiencies.

The national electricity market provides an interesting example of this tension between national and federal policy. In this case, there were likely interjurisdictional spillover benefits of having a single regulator and market, rather than multiple regulators and markets. Although Western Australia and the Northern Territory were excluded from the new federal market, they were not excluded from the new national policy requirements. This is not to suggest that the disaggregation of Western Power, for example, was an inherently suboptimal policy for Western Australia, rather that it was not a federal policy that had obvious spillovers or involvement with the other sub-national jurisdictions. 
The Western Australian government found itself under considerable pressure to have the requisite legislation passed by the State Parliament, with the Treasurer (Hansard 2005) informing Parliament:

We have already suffered a suspension of our competition policy payments of more than \$11 million for 2004-05, and we would be facing a further suspension or deduction of competition policy payments of more than \$11 million for this financial year. If we go past the decision on the competition policy payments this year, we lose any chance of getting back the suspension that was imposed last year and we would most likely lose the more than $\$ 11$ million at stake this year.

The challenge that the NCP posed to the policy autonomy of the states and territories was further evidenced by the NCC's assessment of how the 'public benefit' clause was applied. Subclause 1(3) of the Competition Principles Agreement 1995 (NCC 1998) required that certain matters of 'public benefit' be 'taken into account' during policy and legislative reviews. These matters included:

- government legislation and policies relating to ecologically sustainable development;

- $\quad$ social welfare and equity considerations, including community service obligations;

- government legislation and policies relating to matters such as occupational health and safety, industrial relations and access and equity;

- economic and regional development, including employment and investment growth;

- the interests of consumers generally or of a class of consumers;

- the competitiveness of Australian business; and

- the efficient allocation of resources.

The states and territories understood the clause to mean that policies and legislation could be permitted to restrict competition if it was likely to undermine, for example, community service obligations. The NCC (1996), on the other hand, noted that the subclause did not state the weight that should be attributed to each matter, nor did it set out to explain to what extent sectoral interests should be prioritised over the interests of the entire community. Hence, the clause provided 'an aid to assist review rather than a mechanism for 
imposing blanket exemptions on reform' (NCC 1996, p. 6). Ultimately, the NCC settled upon subclause 5(1) of the Competition Principles Agreement 1995 for guidance, which stated:

The guiding principle is that legislation (including acts, enactments, ordinances or regulations) should not restrict competition unless it can be demonstrated that:

(a) the benefits of the restriction to the community as a whole outweigh the costs; and,

(b) the objectives of the legislation can only be achieved by restricting competition.

The case of retail shopping hours in Western Australia is probably the most striking example of the NCC not accepting a state government's interpretation of the public benefit. Partial reform of trading hours was blocked in the conservativecontrolled Legislative Council. The NCC (2002, 10.6-7) acknowledged this, but argued that Western Australia must still meet its NCP obligations. The NCC (2003, pp. xlii) subsequently recommended that the Western Australian government be penalised $\$ 7.52$ million for not deregulating retail shopping hours. The Western Australian government sought to diffuse the issue by holding a referendum simultaneously with the 2005 state election. Following a resounding result from the public rejecting liberalisation (WAEC 2008), the Western Australian Treasurer wrote to the NCC: 'The letter advised that the Council, to conclude otherwise, would have to assume that it knows more than the public about Western Australia's public interest' (NCC 2005, 14.30). In its 2005 assessment, the NCC $(2005,14.30-31)$ countered:

Clause 5 of the CPA ... requires governments to remove restrictions on competition unless they can demonstrate that the restrictions are warranted - that is, that restricting competition benefits the community overall (being in the public interest) and that the restriction is necessary ... Where a government introduces or retains competition restrictions, and this action was not reasonably drawn from the recommendations of a review, the Council looks for the government to provide a rigorous supporting case, including a demonstration of flaws in the review's analysis and reasoning. The Council considers that conducting a referendum does not absolve a government from its NCP legislation review obligations.

The NCC held firm and withheld the incentive payment. 


\section{A conceptual consideration}

Although both sides present convincing cases about the merits and shortcomings of the NCP as an example of cooperative federalism, it appears that their assessments are focused primarily upon different stages of the policy process. The view that the NCP constituted a successful exercise in cooperative federalism is based upon how the NCP was formulated through intergovernmental relations and constituted in intergovernmental agreements. Certainly, the states, territories and the Commonwealth negotiated over the inclusion of competition payments and the use of template legislation. Officials in the national and sub-national central agencies worked together to prepare the legislation and agreements. Finally, the respective parties willingly signed the three agreements at a COAG meeting.

The view that the NCP was a less than successful example of cooperative federalism reflects a focus upon federal relations during its implementation. From this perspective, the states and territories assumed that the public interest clause would give them some leeway to address local political demands or to reflect local circumstances. Moreover, it was assumed that the process would be transparent and that they would be able to bargain with the Commonwealth if there were disputes over policy implementation. Instead, the lack of transparency in the deliberations over reform payments reinforced a lack of trust among the states and territories towards the Commonwealth. ${ }^{2}$

The works of Sawer (1977) and Painter (1998) — two leading Australian federalism scholars - suggest that the latter view has a stronger case. Over three decades ago, Sawer (1977, p. 6) proposed that cooperative federalism was evidenced by the following characteristics: 'each of the parties to the arrangement has a reasonable degree of autonomy, can bargain about the terms of cooperation, and at least if driven too hard, decline to cooperate'.

This is not to suggest that an absence of conflict between the participants is an essential element of cooperative federalism. On the contrary, it is unlikely that they will always agree. Governments will inevitably differ over values and interests, and will seek to position themselves favourably to achieve desired policy outcomes. As Painter (1998, p. 23) remarked,

\footnotetext{
2 Changes in government since April 1995 also exacerbated tensions between the Commonwealth and the state and territory governments over the NCP. Although a Liberal-National Coalition government was elected nationally in March 1996, at state level, Austalian Labor Party governments were being elected (Tasmania in 1998, Victoria in 1999, Western Australia, the Northern Territory and the Australian Capital Territory in 2001, South Australia in 2002). Following the election of the Labor government in South Australia in March 2002, Australia faced the unique situation of having all states and territories with Labor governments with only the Commonwealth having a Coalition government. Hence, there was at least a perception that the Commonwealth Coalition government was adjudicating on the performance of state and territory Labor governments.
} 
intergovernmental cooperation is tactical, and it is normally temporary because it coexists with competition and conflict (even within the same room). While voluntary, it can be induced and maintained by sanctions, such as the moral sanctions that develop from a 'culture of cooperation'. By definition, however, if the capacity to impose sanctions is too unevenly distributed, we more than likely have coercion ...

It is reasonable to assert that the states and territories entered into the NCP voluntarily. This is consistently raised by officers who view the NCP as a positive example of cooperative federalism - the states and territories were not compelled to sign. Of course, if they did not sign, then they would forfeit the opportunity to receive payments forthcoming to the signatories. After all, the payments were provided as compensation for the cost of implementing the reforms.

It is important to note that although the NCP was based upon agreements freely entered into by the states and territories, the parties did not retain a 'reasonable degree of autonomy' and the 'capacity to impose sanctions' (or provide rewards, depending upon one's perspective) was skewed in favour of the Commonwealth. The decision by the NCC to withhold payments to Western Australia because of its refusal to deregulate trading hours was notable not just because it challenged the autonomy of that state's government to regulate trading hours, but also because it raised the point of who should define the 'public interest'. Clearly, the Western Australian electorate thought that the current regulatory arrangement was in their 'public interest'. The imposition of sanctions from Canberra following a state referendum is consistent with a coercive, rather than cooperative, form of federalism.

As only the Commonwealth could impose penalties, there was an imbalance in power relations that was inconsistent with Painter's notion of cooperation. As was explained above, the NCC acknowledged that the Commonwealth had not been as diligent as most of the states and territories in reviewing its legislation, but that it was unable to do anything about this except to make the public aware of this fact. Only the Commonwealth, through the NCC, could withhold the incentive payments on the grounds of unsatisfactory progress. This imbalance in power relations was further highlighted by the position of the Commonwealth Minister as the final judge on the matter. Certainly, the states and territories retained the right not to undertake every reform called for under the NCP, however, such a decision would draw sanctions more in keeping with coercive forms of federalism.

Ultimately, cooperative federalism as a concept is not meaningful unless it is applied to both the formulation and implementation stages of a policy. The NCP was defined as a policy response to perceived inefficiencies in the Australian economy and was continually justified and evaluated in these terms. Many 
policy officers, particularly from state central agencies, indicated that this was their prime concern — not federal relations. The implication for Australian federalism and cooperative federalism, in particular, was that the reform program took precedence over notions of cooperation between the federal partners; in effect, the ends justified the means. It could be argued that NCP had more in common with what has been termed 'pragmatic federalism' (Hollander and Patapan 2007).

\section{Conclusion}

While it was instrumental in advancing microeconomic reform, the National Competition Policy was far from a perfect example of cooperative federalism. On the one hand, it was based upon agreements entered into voluntarily by the Commonwealth, states and territories. On the other hand, the Commonwealth did not implement reforms as diligently as the states, some reforms were expensive to administer, and others imposed disproportionate hardships upon some communities and businesses. Contrary to its remit, the National Competition Council endeavoured to influence policy outcomes, rather than simply monitor implementation of NCP obligations. An examination of the NCP from the theoretical perspectives offered by Sawer and Painter reveal that it did not offer the states sufficient policy autonomy and bargaining power to fully constitute cooperative federalism. Nevertheless, it is still one of our best examples of how the federal partners can work together to achieve mutually desired outcomes.

\section{References}

Banks, G. 2005, 'Structural Reform Australian-Style: Lessons for others?', Presentation to the IMF, World Bank and OECD, May 2005. Available at: http://www.pc.gov.au/news-and-media/chairmans-speeches/gary-banks/ cs20050601/cs20050601.pdf.

Boswell, R. 1996, 'The Implications of National Competition Policy', Australian Journal of Public Administration 55(2), pp. 79-82.

Butler, G. 1996, 'National Competition Policy: The downside', Australian Journal of Public Administration 55(2), pp. 104-106.

Carver, L. 1996. 'Consumers/Citizens and the National Competition Policy', Australian Journal of Public Administration 55(2), pp. 88-93. 
Commonwealth of Australia 1995, Competition Policy Reform Act 1995. Available at: http://www.comlaw.gov.au/Details/C2004A04938.

COAG (Council of Australian Governments) 1994a, COAG Communiqué, 25 February. Available at: http://archive.coag.gov.au/coag_meeting_ outcomes/1994-02-25/index.cfm.

COAG 1994b, 'Attachment A: Water resource policy'. Available at: http://archive. coag.gov.au/coag_meeting_outcomes/1994-02-25/docs/attachment_a.cfm.

COAG 1995a, COAG Communiqué, 11 April. Available at: http://archive.coag. gov.au/coag_meeting_outcomes/1995-04-11/index.cfm.

COAG 1995b, 'Attachment A: Agreement to implement the national competition policy and related reforms', 11 April. Available at: http://archive.coag.gov. au/coag_meeting_outcomes/1995-04-11/docs/attachment_a.cfm.

COAG 1995c, 'Attachment: Conditions of payments to the states', 11 April. Availableat:http://archive.coag.gov.au/coag_meeting_outcomes/1995-04-11/ docs/attachment_a_parta.cfm.

ERA (Economic Regulation Authority (Western Australia)) 2009, 'Strategic Plan 2008-10'. Available at: http://www.era.wa.gov.au/ cproot/6704/2/20090325\%20ERA\%20Strategic\%20Plan\%202008-10.pdf.

Fenna, A. 2007, 'The Division of Powers in Australia: Subsidiarity and the single market', Public Policy 2(3), pp. 175-194.

Hansard (Western Australia), 2005, 'Business of the House (Assembly)', extract from Hansard, Thursday 22 September. Available at: http://www.parliament. wa.gov.au/Hansard/hansard.nsf/0/3410d49a9cldb017c8257570001285bf/\$F ILE/A37\%20S1\%2020050922\%20p5928b-5930a.pdf.

Hilmer, F., M. Rayner and G. Taperell (The Independent Committee of Inquiry into a National Competition Policy) 1993, 'National Competition Policy'. Available at: http://www.ncc.gov.au/images/uploads/Hilmer-001.pdf.

Hollander, R. 2006, 'National Competition Policy, Regulatory Reform and Australian Federalism: Research and evaluation', Australian Journal of Public Administration 65(2), pp. 33-47.

Hollander, R. and G. Curran 2001, 'The Greening of the Grey: National competition policy', Australian Journal of Public Administration 60(3), pp. 42-55. 
Hollander, R. and H. Patapan 2007, 'Pragmatic Federalism: Australian federalism from Hawke to Howard', Australian Journal of Public Administration 66(3), pp. 280-297.

NCC (National Competition Council) 1996, 'Considering the Public Interest under the National Competition Policy'. Available at: http://ncp.ncc.gov.au/ docs/PIRePu-001.pdf.

NCC 1998, 'Compendium of National Competition Policy Agreements', 2nd ed. Available at: http://www.ncc.gov.au/images/uploads/PIAg-001.pdf.

NCC 2002, 'Assessment of Governments' Progress in Implementing the National Competition Policy and Related Reforms, Volume One: Assessment'. Available at: http://ncp.ncc.gov.au/docs/2002\%20assessment.pdf.

NCC 2003, 'Assessment of Governments' Progress in Implementing the National Competition Policy and Related Reforms, Volume One: Overview of the national competition policy and related reforms'. Available at: http://ncp. ncc.gov.au/docs/2003\%20assessment.pdf.

NCC 2004, 'Submission to the Productivity Commission Review of National Competition Policy Arrangements'. Available at: http:/www.pc.gov.au/ inquiries/completed/national-competition-policy/submissions/71/sub071. pdf.

NCC 2005, 'Assessment of Governments' Progress in Implementing the National Competition Policy and Related Reforms: 2005'. Available at: http://ncp.ncc. gov.au/docs/2005\%20assessment.pdf.

New South Wales Government 2004, 'Productivity Commission Review of National Competition Policy Arrangements: NSW Government submission'. Available at: http://www.pc.gov.au/inquiries/completed/nationalcompetition-policy/submissions/99/sub099.pdf.

Painter, M. 1998, Collaborative Federalism: Economic Reform in the 1990s, Cambridge University Press, Cambridge.

Productivity Commission 2005, 'Review of National Competition Policy Reforms', Productivity Commission Inquiry Report No. 33. Available at: http://www.pc.gov.au/inquiries/completed/national-competition-policy/ report/ncp.pdf.

Sawer, G. 1977, Federation Under Strain: Australia 1972-1975. Melbourne University Press, Melbourne. 
Sims, R. 1999, 'In Defence of Competition: The successful application of competition policy in NSW Rail', Australian Journal of Public Administration 58(4), pp. 96-104.

Thomas, C. 1996, 'Why National Competition Policy?', Australian Journal of Public Administration 55(2), pp. 100-103.

Victoria, State of 2004, 'Victorian Government Submission: Inquiry into national competition policy arrangements'. Available at: http:/www.pc.gov.au/ inquiries/completed/national-competition-policy/submissions/51/sub051. pdf.

WAEC (Western Australia Electoral Commission) 2008, 'Referendum Results'. Available at: http://www.elections.wa.gov.au/elections/referendums/pastreferendums/sr2005. 
This text taken from New Accountabilities, New Challenges, edited by John Wanna, Evert A. Lindquist and Penelope Marshall, published 2015 by ANU Press, The Australian National University, Canberra, Australia. 